Bangladesh J. Plant Taxon. 20(1): 61-65, 2013 (June)

(C) 2013 Bangladesh Association of Plant Taxonomists

\title{
TAXONOMIC SIGNIFICANCE OF SPERMODERM PATTERN
} IN CUCURBITACEAE

\author{
M. Ajmal Ali ${ }^{1}$, Fahad M.A. Al-Hemaid, Arun K. Pandey ${ }^{2}$ and Joongku Lee ${ }^{3}$ \\ Department of Botany and Microbiology, College of Science, King Saud University, \\ Riyadh-11451, Saudi Arabia.
}

Keywords: Cucurbitaceae; SEM; Spermoderm; Testa.

\begin{abstract}
Studies on spermoderm using scanning electron microscope (SEM) were undertaken in 12 taxa under 11 genera of the family Cucurbitaceae sampled from India, China and Korea. The spermoderm pattern in the studied taxa varies from rugulate, reticulate to colliculate type. The spermoderm shows rugulate type in Benincasa hispida and Sicyos angulatus; reticulate type in Citrullus colocynthis, Cucumis melo var. agrestis, Diplocyclos palmatus, Hemsleya longivillosa, Luffa echinata, Momordica charantia, $M$. cymbalaria, Schizopepon bryoniifolius, and Trichosanthes cucumerina; and colliculate type in Gynostemma laxiflorum. The present study clearly reveals that the testa features greatly varies across the genera which can be used as micromorphological markers for identification as well as character states for deducing relationship of the taxa within the family.
\end{abstract}

\section{Introduction}

Spermoderm refers to the pattern present on the seed coat of mature seeds. Seed characteristic, particularly exomorphic features as revealed by scanning electron microscopy, have been used by many workers in resolving taxonomic problems (Koul et al., 2000; Pandey and Ali, 2006) and evolutionary relationships (Kumar et al., 1999; Segarra and Mateu, 2001).

Cucurbitaceae, with c. 800 species under 130 genera (Schaefer and Renner, 2011) are among the economically most important plant families (Kirtikar and Basu, 1975; Chakravarty, 1982; Ali and Pandey, 2006). Of the 130 genera, c. 50 contains single species, which illustrates the difficulties in deducing relationships within the family. Jeffrey (2005) divided the family Cucurbitaceae into 11 tribes under two subfamilies viz., the Nhandiroboideae (Zanonioideae, with 60 species under 19 genera) and Cucurbitoideae (with c. 740 species under 111 genera). Nhandiroboideae are characterized by a gynoecium with three or rarely two, free styles, while Cucurbitoideae have the styles united into a single column. The most important diagnostic characters for the genera and tribes of Cucurbitaceae come from androecium and gynoecium morphology, type of tendril branching, pollen structure and seed coat (Jeffrey, 2005). Recently Schaefer and Renner (2011) have divided the family Cucurbitaceae into 95 genera in 15 tribes. The testa of Cucurbitaceae is formed by the outer integument and consists of a lignified epidermis, a hypodermis is of one or many layers of sclerotic cells, and an inner one-layered protective cover that in mature seeds is heavily lignified (Singh and Dathan, 2001).

\footnotetext{
${ }^{1}$ Corresponding author. Email: majmalali@rediffmail.com ${ }^{2}$ Department of Botany, University of Delhi, Delhi-110007, India.

${ }^{3}$ International Biological Material Research Center, Korea Research Institute of Bioscience and Biotechnology, Daejeon- 305806, South Korea.
} 
Seed coat exhibits complex and highly diverse morphology and anatomy, providing valuable taxonomic characters. Despite seed coat morphology were studied in different groups of plants, no detailed work on spermoderm morphology in the systematics of Cucurbitaceae was conducted so far. The main objective of the present study is to evaluate taxonomic significance of spermoderm pattern in some members of the family Cucurbitaceae.

\section{Materials and Methods}

The seeds for the present investigation were collected from nature during field trips or were procured from herbarium specimens (Table 1). Dry mature seeds were directly mounted on double-sided carbon tape which was affixed on aluminum stub. Seeds were then coated with very thin layer of gold in a sputter coater unit (Hitachi E-1010), and observed with a Hitachi S3400-N scanning electron microscope at $20 \mathrm{KV}$. Scanning Electron Microscopy was performed at Korea Research Institute of Bioscience and Biotechnology, Daejeon, South Korea. Renner and Pandey (2012), Lu et al. (2011) and Park (2007) were followed for taxon nomenclature. For terminology of spermoderm, Radford et al. (1974), Barthlot (1990) and Barthlot et al. (1998) were followed.

\section{Results and Discussion}

In the present study, three different patterns of spermoderm (i.e. rugulate, reticulate and colliculate) were observed in the studied taxa (Table 1). The spermoderm pattern in Benincasa hispida was found rugulate, rugae were unevenly distributed and compactly arranged. Some rugae were raised at certain places and were larger or smaller in appearance (Fig. 1).

In Citrullus colocynthis the spermoderm pattern was reticulate with thin walled polygonal reticulae. The reticulae were compactly arranged and the testa cell surface showed transverse striation (Fig. 2). In Cucumis melo var. agrestis the spermoderm pattern was reticulate type. The testa cells were rectangular and compactly arranged. The flakes of waxy deposition were observed sporadically over the surface (Fig. 3).

Diplocyclos palmatus showed the reticulate pattern of spermoderm with distinct anticlinal and periclinal walls. The testa cells were polygonal with small protuberances covered with crystal like structures. These structures were unique to this species and were not found in any other cucurbits studied presently. Each testa cell presented small protuberances over which crystal like structures were formed (Fig. 4). In Gynostemma laxiflorum the spermoderm pattern was strongly colliculate type and the seed surface showed raised projections due to overgrowth of the testa cells and distributed throughout the seeds surface. The testa cells were smooth in appearance due to thin film of wax (Fig. 5). Hemsleya longivillosa exhibited reticulate type of spermoderm where the testa cells were thick walled, hexagonal, lack up of wax deposition, compactly arranged and the cell surface were granulated (Fig. 6). Luffa echinata presented reticulate type of spermoderm pattern. The reticulae were compactly arranged and at certain places they were superimposed in such a way that the spermoderm appeared to be rugulate (Fig. 7). In Momordica charantia the spermoderm was reticulate with thick walled testa cells. Testa cell wall was more or less filling the cells which gave a reticulate-punctate appearance (Fig. 8). M. cymbalaria shows reticulate type of spermoderm pattern. The testa cells were hexagonal, compactly arranged and were covered with thin layer of wax or sometimes globular granules spread over the testa cell surface or on the testa cell wall which masking the nature of spermoderm (Fig. 9). In Schizopepon bryoniifolius the spermoderm pattern was of reticulate type and the reticulae were thin walled. The testa cells were elongated and polygonal. Some of the testa cells were transversely septate (Fig. 10). Sicyos angulatus showed the rugulate type of spermoderm with prominent rugae which anastomose each other giving an interwoven appearance. The rugae were separated from one another by deep 
grooves. The spermoderm shows a few sporadically distributed waxy flakes (Fig. 11). In Trichosanthes cucumerina the spermoderm was reticulate and the reticulae were large, polygonal and prominent with thick layer of wax giving smooth appearance to the surface (Fig. 12).

Table 1. Origin of taxa included in the present study and spermoderm pattern.

\begin{tabular}{|c|c|c|c|c|}
\hline No. & Species & Locality & Voucher specimen & Spermoderm \\
\hline 1 & $\begin{array}{l}\text { Benincasa hispida (Thunb.) } \\
\text { Cong }\end{array}$ & $\begin{array}{l}\text { Bhagalpur, Bihar, } \\
\text { India }\end{array}$ & $\begin{array}{l}\text { Ali and Pandey } 1001 \\
\text { (BHAG) }\end{array}$ & Rugulate \\
\hline 2 & $\begin{array}{l}\text { Citrullus colocynthis (L.) } \\
\text { Schard. }\end{array}$ & $\begin{array}{l}\text { Kishanganj, Bihar, } \\
\text { India }\end{array}$ & $\begin{array}{l}\text { Ali and Pandey } 1050 \\
\text { (BHAG) }\end{array}$ & Reticulate \\
\hline 3 & $\begin{array}{l}\text { Cucumis melo var. agrestis } \\
\text { Naud. }\end{array}$ & Purnia, Bihar, India & $\begin{array}{l}\text { Ali and Pandey } 1009 \\
\text { (BHAG) }\end{array}$ & Reticulate \\
\hline 4 & $\begin{array}{l}\text { Diplocyclos palmatus (L.) } \\
\text { Jeffrey }\end{array}$ & $\begin{array}{l}\text { Bhagalpur, Bihar, } \\
\text { India }\end{array}$ & $\begin{array}{l}\text { Ali and Pandey } 1083 \\
\text { (BHAG) }\end{array}$ & Reticulate \\
\hline 5 & $\begin{array}{l}\text { Gynostemma laxiflorum C.Y. } \\
\text { Wu \& S.K. Chen }\end{array}$ & Anhui, China & X.F. Gao 390 (KUN) & Colliculate \\
\hline 6 & $\begin{array}{l}\text { Hemsleya longivillosa C.Y. Wu } \\
\text { \& C.L. Chen }\end{array}$ & Yunnan, China & $\begin{array}{l}\text { s.n., Acc. No. } \\
0362096 \text { (KUN) }\end{array}$ & Reticulate \\
\hline 7 & Luffa echinata Roxb. & Katihar, Bihar, India & $\begin{array}{l}\text { Ali and Pandey } 1093 \\
\text { (BHAG) }\end{array}$ & Reticulate \\
\hline 8 & Momordica charantia L. & $\begin{array}{l}\text { Bhagalpur, Bihar, } \\
\text { India }\end{array}$ & $\begin{array}{l}\text { Ali and Pandey } 1111 \\
\text { (BHAG) }\end{array}$ & Reticulate \\
\hline 9 & M. cymbalaria Fenzl ex Naudin & $\begin{array}{l}\text { Andhra Pradesh, } \\
\text { India }\end{array}$ & $\begin{array}{l}\text { S. Karuppusamy } \\
28631 \text { (SKU) }\end{array}$ & Reticulate \\
\hline 10 & $\begin{array}{l}\text { Schizopepon bryoniifolius } \\
\text { Maxim. }\end{array}$ & Gangwon-do, Korea & $\begin{array}{l}\text { Hyeong-Kyu Lee } \\
00859 \text { (KRIB) }\end{array}$ & Reticulate \\
\hline 11 & Sicyos angulatus L. & $\begin{array}{l}\text { Gyeonbsanguk-do, } \\
\text { Korea }\end{array}$ & $\begin{array}{l}\text { G.Y. Chung s.n. } \\
\text { (KRIB) }\end{array}$ & Rugulate \\
\hline 12 & Trichosanthes cucumerina L. & $\begin{array}{l}\text { Bhagalpur, Bihar, } \\
\text { India }\end{array}$ & $\begin{array}{l}\text { Ali and Pandey } 1113 \\
\text { (BHAG) }\end{array}$ & Reticulate \\
\hline
\end{tabular}

Herbaria: BHAG (Department of Botany, Tilka Manjhi Bhagalpur University, Bhagalpur, Bihar, India); KRIB (Korea Research Institute of Bioscience and Biotechnology, Daejeon, South Korea); KUN (Kunming Institute of Botany, Chinese Academy of Sciences, China); SKU (Sri Krishnadevaraya University, Anantapur, Andhra Pradesh, India).

The systematic application of seed surface features, as observed under scanning electron microscope is tremendous considering that seed characters are only slightly influenced by environmental conditions. High structural diversity of seed provides most valuable criteria for classification at species and family level (Barthlott, 1984); therefore, spermoderm surface patterns have been extensively utilized as a secondary taxonomic characters (see Pandey and Ali, 2006). In the present study, the spermoderm pattern in the studied taxa varies from rugulate, reticulate to colliculate. The spermoderm shows rugulate pattern in Benincasa hispida, Sicyos angulatus; reticulate in Citrullus colocynthis, Cucumis melo var. agrestis, Diplocyclos palmatus, Hemsleya longivillosa, Luffa echinata, Momordica charantia, M. cymbalaria, Schizopepon bryoniifolius, Trichosanthes cucumerina to strongly colliculate in Gynostemma laxiflorum. The results of the present study reveals that even within the similar pattern of spermoderm, the testa features greatly 
varies from genera to genera which can be used as micromorphological markers for identification as well as character states for deducing generic and specific relationship within the family.
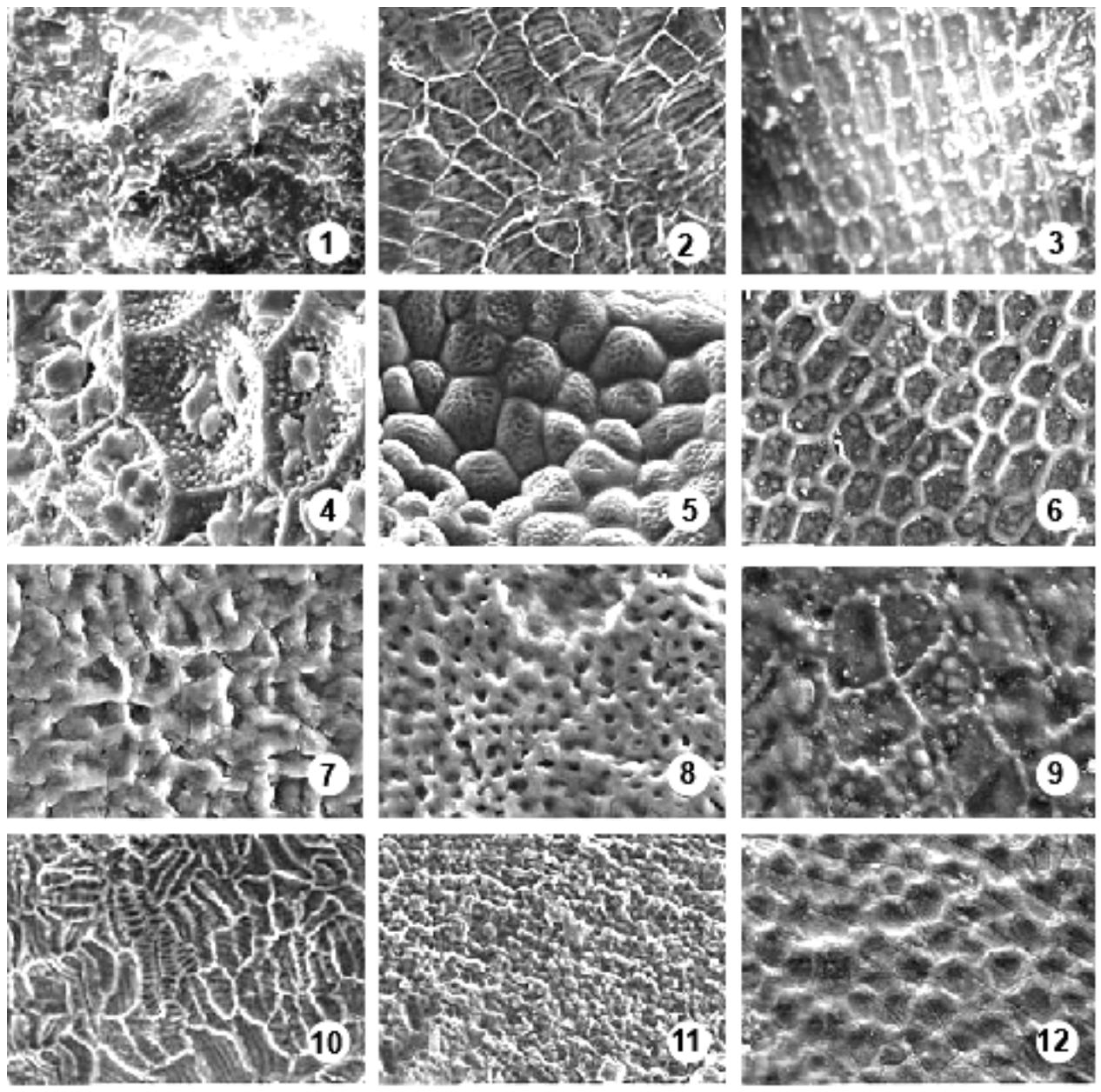

Figs 1-12. Scanning electron micrograph of the seed surface in Cucurbitaceae: 1 . Benincasa hispida $\times 400$ (rugulate); 2. Citrullus colocynthis $\times 400$ (reticulate); 3 . Cucumis melo var. agrestis $\times 400$ (reticulate); 4 . Diplocyclos palmatus $\times 1000$ (reticulate); 5 . Gynostemma laxiflorum $\times 600$ (colliculate); 6 . Hemsleya longivillosa $\times 400$ (reticulate); 7 . Luffa echinata $\times 1000$ (reticulate); 8 . Momordica charantia $\times 700$ (reticulate); 9. Momordica cymbalaria $\times 1000$ (reticulate); 10. Schizopepon bryoniifolius $\times 400$ (reticulate); 11. Sicyos angulatus $\times 300$ (rugulate); 12 . Trichosanthes cucumerina $\times 320$ (reticulate).

\section{Acknowledgements}

The authors would like to extend their sincere appreciation to the Deanship of Scientific Research at King Saud University for its funding of this research through the Research Group Project No. RGP-VPP-195. 


\section{References}

Ali, M.A. and Pandey, A.K. 2006. Cucurbitaceae of Bihar: diversity and conservation. In: Trivedi, P.C. (Ed.), Global biodiversity status and conservation. Pointer Publisher Jaipur, India, pp. 250-260.

Barthlott, W. 1984. Microstructural features of seed surface. In: Heywood, V.H. and Moore, D.M. (Eds), Current Concept in Plant Taxonomy. Academic Press, London, pp. 95-105.

Barthlott, W. 1990. Scanning electron microscopy of the epidermal surface in plants. In: Claugher, D. (Ed.), Scanning Electron Microscopy in Taxonomy and Functional Morphology. Clarendon Press, Oxford, pp. 69-94.

Barthlott, W., Neinhuis C., Cutler, D., Ditsch, F., Meussel, I., Theisen, I., and Wilhelm, H. 1998. Classification and terminology of plant epicuticular waxes. Bot. J. Lin. Soc. 126: 237-260.

Chakravarty, H.L. 1982. Cucurbitaceae In: Jain, S.K. (Ed.) Fascicles of Flora of India, No. 11, Botanical Survey of India, Calcutta.

Jeffrey, C. 2005. A new system of Cucurbitaceae. Bot. Zhurn. 90: 332-335.

Kirtikar, K. and Basu, B.D. 1975. Indian Medicinal Plants (Reprint Edition), Vol. II. Bishen Singh Mahendra Pal Singh, Dehra Dun, India, pp. 1106-1115.

Koul, K.K., Ranjan, N. and Raina, S.N. 2000. Seed coat microsculpturing in Brassica and allied genera (subtribe Brassicinae, Raphaninae, Moricandiinae). Ann. Bot. 86: 385-395.

Kumar, P.P., Rao C.D., Rajasegar, G. and Rao, A.N. 1999. Seed surface architecture and random amplified polymorphic DNA profiles of Paulownia fortunei, P. tomentosa and their hybrid. Ann. Bot. 83: 103107.

Lu, A., Huang, L., Chen, S.K. and Jeffrey, C. 2011. Cucurbitaceae. In: Wu, Z.Y., Raven, P.H., Hong, D.Y. (Eds), Flora of China, Vol. 19. Missouri Botanical Garden Press, St. Louis.

Pandey, A.K. and Ali, M.A. 2006. Testa topography in Papillionoidae and its taxonomic significance. In: Pandey, A.K., Wen, J., Dogra, J.V.V. (Eds), Plant Taxonomy: Advances and Relevance. CBS Publisher and Distributor, New Delhi, India, pp. 529-541.

Park, C. 2007. The Genera of Vascular Plants of Korea. Academy Publishing Co., Seoul, South Korea.

Radford, A.E., Dickison, W.C., Massey, J.R. and Bell, C.R. 1974. Vascular Plant Systematics. Harper and Row publishers, New York.

Renner, S.S. and Pandey, A.K. 2012. The Cucurbitaceae of India: Accepted names, synonyms, geographic distribution, and information on images and DNA sequences. PhytoKeys 20: 53-118.

Schaefer, H. and Renner, S.S. 2011. Phylogenetic relationships in the order Cucurbitales and a new classification of the gourd family (Cucurbitaceae). Taxon 60(1): 122-138.

Segarra, J.G. and Mateu, I. 2001. Seed morphology of Linaria species from eastern Spain: identification of species and taxonomic implications. Bot. J. Linn. Soc. 135: 375-389.

Singh, D. and Dathan, A.S.R. 2001. Development and structure of seed coat in the Cucurbitaceae and its implications in systematics. In: Chauhan, S.V.S. and Chaturvedi, S.N. (Eds), Botanical Essays: Tribute to Professor Bahadur Singh. Printwell Publishers Distributors, Jaipur, India, pp. 87-114. 